\title{
EXPERIMENTAL STUDY OF EFFECT OF FIBER ORIENTATION ON THE FLEXURAL STRENGTH OF GLASS/EPOXY COMPOSITE MATERIAL
}

\author{
Sandeep M.B ${ }^{1}$, D.Choudhary ${ }^{2}$, Md. Nizamuddin Inamdar ${ }^{3}$, Md. Qalequr Rahaman ${ }^{4}$ \\ ${ }^{1,2,3,4}$ Department of Mechanical Engineering, Guru Nanak Dev Engineering College Bidar, India \\ Email:sandeep026@gmail.com
}

\begin{abstract}
Polymer matrix composite materials are anisotropic in nature, the mechanical properties of these materials are different for different constituents and orientation of reinforcing material. In this paper, the effect of fiber orientation on the flexural strength for pure glass/epoxy composite material is presented. The experimental results showed the difference in flexural strength in bidirectional glass fibers at $0-90^{\circ}$ and $-45+45^{\circ}$ orientation
\end{abstract}

Keywords: Composite materials, Flexural strength, Epoxy resin, Glass fibers

\section{INTRODUCTION}

Composite material is combination of two or more dissimilar materials that are combined in macroscopic level but, these materials chemically not combined. These materials are again classified in to metal matrix composites, polymer matrix composites and ceramics. In these materials one is matrix material and another is reinforcing material. Depending on the applications these materials compositions are changed. The polymer matrix composites are being used in aerospace, naval, automobiles and civil engineering as structural materials because of its high strength to weight ratio, lower density, low coefficient of thermal expansion, lower strains, higher thermal resistance and corrosion resistance. These material are future of engineering materials, they will replace the use of metals in structural applications.

An experimental investigation was conducted by K.G Satish et al. [1] to study the effect of hybrid composite specimen subject to in-plane tensile and compressive loading and showed laminated specimens with higher percentage of steel sustain greater loads irrespective of fiber orientations. Keshavamurthy $\mathrm{Y}$ C et al. [2] investigated the tensile properties of fiber reinforced angle ply laminated composites. Glass/Epoxy with $0^{0}$ fiber orientation yielded in high strength when compared with $30^{\circ} \& 45^{\circ}$ for the same load, size \& shape. P. Feraboli et al. [3] investigated inter laminar shear strength of carbon/ epoxy laminates. The finite element analyses were developed using ANSYS software and studied the mechanics of delamination in fourpoint bending. O.Velecela et al. [4] studied steady state quasistatic compression of GFRP monolithic laminates \& sandwich panels made of randomly oriented continuous filament mat. The effect of face laminate thikness on impact energy absorption is studied. The experimental data showed, high value of energy absorbed per unit mass were predominant failure of the thickest monolithic laminats. Momchil Dimchev et al. [5] studied the effect of carbon nanofibers on the tensile and compression properties of hollow particles filled composites. The result of this study showed, the addition of $0.25 \mathrm{wt}$. \% carbon nanofibers result in improvement in tensile modulus and strength compared to similar syntactic foam compositions without nanofibers. $\mathrm{R}$ Velmurugan et al. [6] studied tensile, flexural, shear and impact properties of glass/palmyra fiber waste sandwich composites and found 58-65 wt\% fibers showed good flexural strength. S. Channabasavaraju et al. [7] evaluated tensile and flexural properties of glass, graphite and kevlar fiber reinforced polymer matrix composites. The results have showed the variation in the fiber types has significant effect on the tensile and flexural properties of composite materials. Vinod B et al. [8] studied the effect of fiber orientation on the flexural properties of PALF reinforced bisphenol composites. The results revealed that, fiber orientation have great effect on the flexural properties of fiber reinforced polymer matrix composites.

There are various parameters of the materials that lead to the desired material properties. So, there is scope of investigating the parameters pertaining to the desired material properties. Based on the literature survey, we have considered glass/epoxy polymer matrix composite for studying the effect of fiber orientation on the flexural properties of the material.

\section{MATERIALS AND METHODS}

The material selected for the present study is E-glass fiber of $360 \mathrm{GSM}$ as reinforcing material and epoxy resin as matrix material. The properties of the material are presented in table 2.1. The samples were prepared as per ASTM D790-10 using hand layup technique and subjected for flexural test in a computerized universal testing machine. 
Table 2.1 Properties of materials

\begin{tabular}{|c|c|c|c|}
\hline & $\begin{array}{l}\text { Reinforcing } \\
\text { material }\end{array}$ & $\begin{array}{l}\text { Matrix } \\
\text { material }\end{array}$ & Hardener \\
\hline & $\begin{array}{l}\text { E-glass fiber of } \\
\text { 360GSM } \\
\text { Bidirectional } \\
\text { woven roving }\end{array}$ & $\begin{array}{l}\text { Epoxy } \\
\text { Resin } \\
\text { (LY556 } \\
\text { [Araldite] } \\
\end{array}$ & $\begin{array}{l}\mathrm{HY} \\
\text { [Aradur] } \\
\text { At } 20^{\circ} \mathrm{C} 1: 1 \text { in } \\
\text { water }\end{array}$ \\
\hline 葛 & 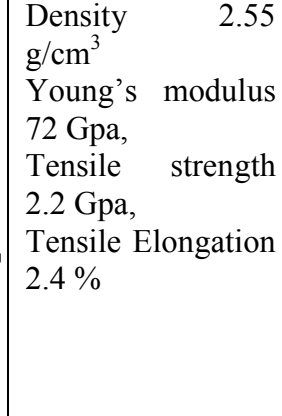 & $\begin{array}{l}\text { Viscosity at } \\
25^{\circ} \mathrm{C} \text { (ISO } \\
9371 \mathrm{~B} \text { ) } \\
10000 \\
12000 \\
{[\mathrm{MPa} \mathrm{s}]} \\
\text { Density at } \\
25^{\circ} \mathrm{C} \text { (ISO } \\
1675) \quad 1.15 \\
- \\
{\left[\mathrm{g} / \mathrm{cm}^{3}\right]}\end{array}$ & $\begin{array}{l}\text { Boiling point } \\
>200^{\circ} \mathrm{C}, \\
\text { Thermal } \\
\text { decomposition } \\
>200^{\circ} \mathrm{C} \text {, } \\
\text { Flash point : } \\
110^{\circ} \mathrm{C} \\
\text { Density } \\
1 \mathrm{~g} / \mathrm{cm}^{3}\end{array}$ \\
\hline
\end{tabular}

\section{EXPERIMENTAL}

\subsection{Flexural Strenght Test}

Flexural strength is a material ability to resist deformation under bending load. Flexural testing was performed on the bidirectional glass/epoxy specimens of size $64 \times 16 \times 4$ and $96 \times 24 \times 6 \mathrm{~mm}$. The specimens were subjected to 3 point bending test on computer controlled UTM of $10 \mathrm{kN}$ capacity supplied by Kalpak Instruments and controls, Pune, India in BISS laboratory, Bangalore as per ASTM D 790-10. The distance between the two support was maintained at $72 \mathrm{~mm}$ for $6 \mathrm{~mm}$ thick specimen and $42 \mathrm{~mm}$ for $4 \mathrm{~mm}$ thick specimen. The loading arrangement is shown in figure $1 \&$ 2. The data is recorded during the 3-point bend test to evaluate the flexural strength.

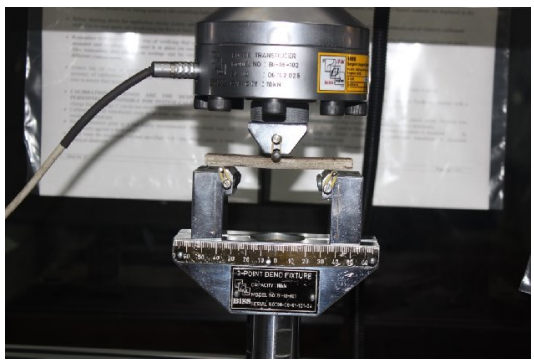

Fig 1 Flexural loading arrangement for $6 \mathrm{~mm}$ thick specimen

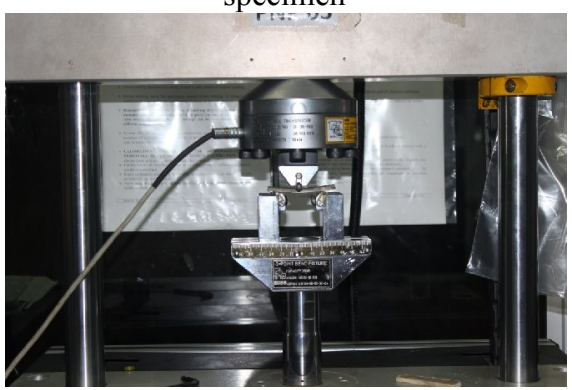

Fig. 2 Flexural loading arrangement for $4 \mathrm{~mm}$ thick specimen

\section{RESULTS AND DISCUSSION}

\subsection{Flexural Strength of $4 \mathrm{~mm}$ Thick $-45+45^{\circ}$ Orientation Glass/Epoxy Composite}

Flexural strength is a mechanical parameter for the material property, which measures the bending strength or fracture strength of the materials which is also called as 3-point bending test. The behavior of the test sample of $4 \mathrm{~mm}$ thick $-45+45^{0}$ orientation glass/epoxy composite is presented interms of load verses deflection in figure 1 . The fracture occurres at a load of $1.1 \mathrm{kN}$ with a deflection of $3 \mathrm{~mm}$. The flexural strength is calculated by using equation number 1 . The fractured specimen is shown in figure 4 . The value of flexural strength for this specimen is 270.7 Mpa.

Where, $\sigma=$ Flexural strength, $F=$ Load at fracture point in $\mathrm{N}, \mathrm{B}=$ width of rectangular section, $\mathrm{D}=$ thickness of rectangular section

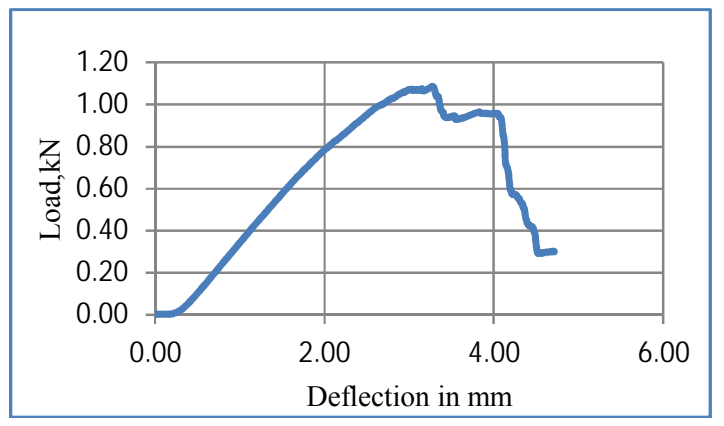

Fig 3. Load vs deflection of $4 \mathrm{~mm}$ thick $-45+45^{\circ}$ orientation glass/epoxy composite

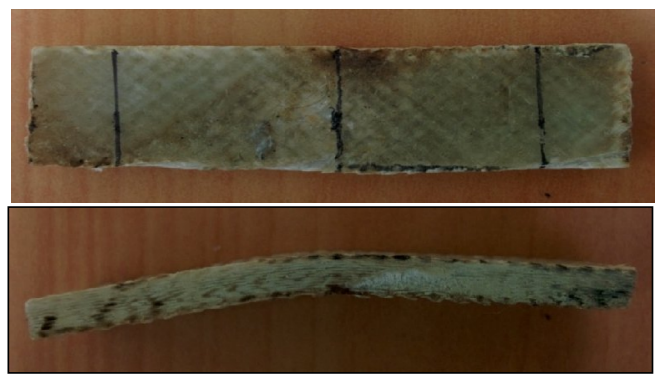

Fig 4. Fractured specimen

\subsection{Flexural Strength of $6 \mathrm{~mm}$ Thick $-45+45^{0}$}

\section{Orientation Glass/Epoxy Composite}

The load verses displacement plot for $6 \mathrm{~mm}$ thick $-45+45^{0}$ orientation glass/epoxy composite is shown in figure 5 . The fracture occurs at a load of $3.7 \mathrm{kN}$ with a deflection of 3.5 $\mathrm{mm}$ and the flexural strength is $462 \mathrm{Mpa}$. Figure 6 shows the fractured specimen. 


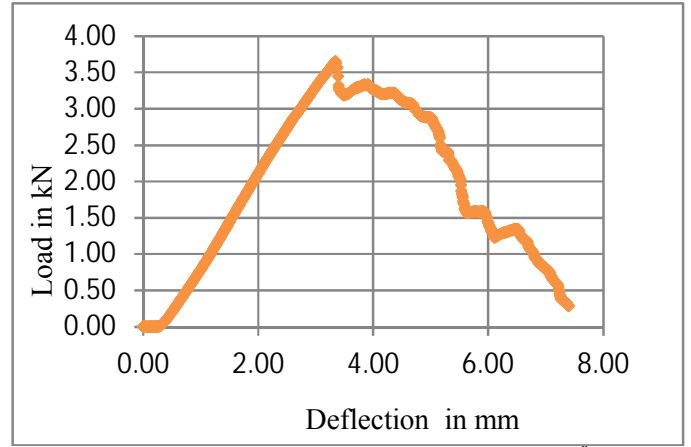

Fig 5. Load vs deflection of $6 \mathrm{~mm}$ thick $-45+45^{0}$ orientation glass/epoxy composite

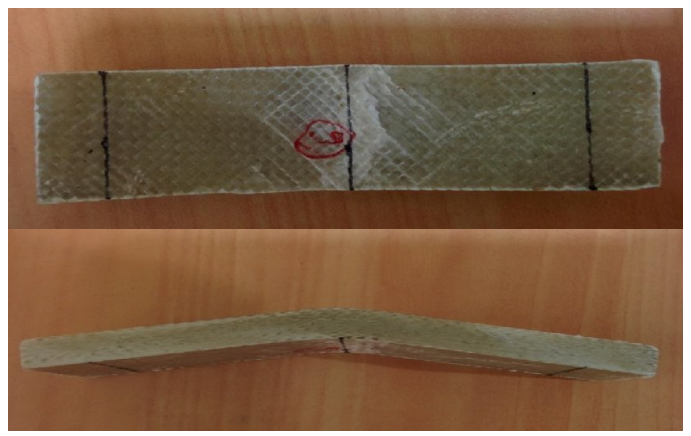

Fig 6. Fractured specimen

\subsection{Flexural Strength of $4 \mathrm{~mm}$ Thick $0-90^{0}$ Orientation Glass/Epoxy Composite}

The load verses displacement plot for $4 \mathrm{~mm}$ thick $0-90^{0}$ orientation glass/epoxy composite is shown in figure 7 . The fracture load for this specimen is $0.92 \mathrm{kN}$ with a deflection of $8 \mathrm{~mm}$ and the value of flexural strength for this specimen is $226.4 \mathrm{Mpa}$. The fractured specimen is shown in figure 8 .

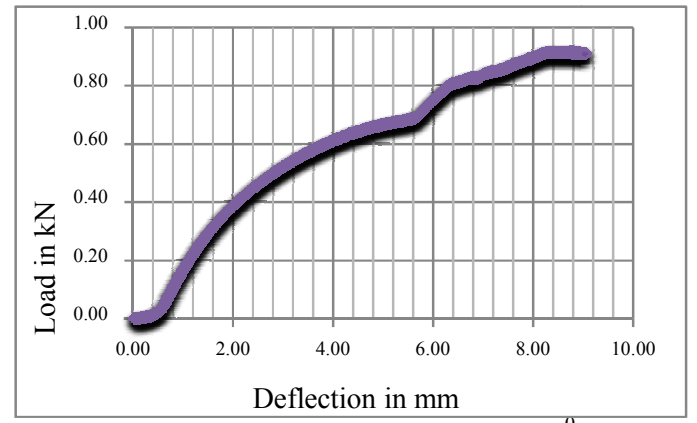

Fig 7. Load vs deflection of $4 \mathrm{~mm}$ thick $0-90^{\circ}$ orientation glass/epoxy composite

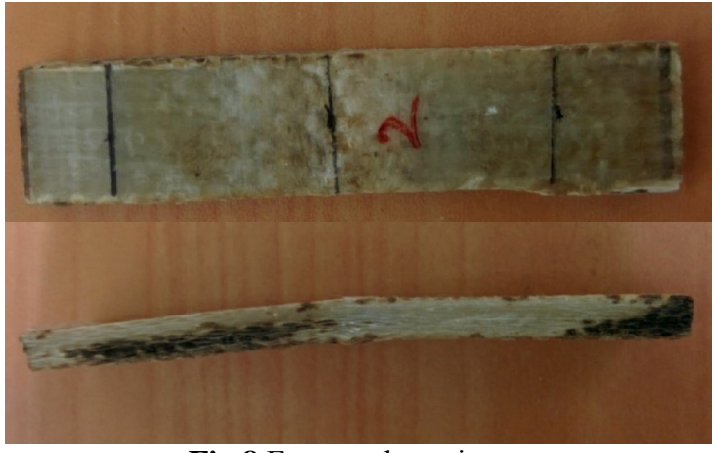

Fig 8.Fractured specimen

\subsection{Flexural Strength of $6 \mathrm{~mm}$ Thick $0-90^{0}$ Orientation Glass/Epoxy Composite}

The load verses displacement plot for $6 \mathrm{~mm}$ thick $0-90^{0}$ orientation glass/epoxy composite is shown in figure 9 . The fracture load for this specimen is recorded as $2.25 \mathrm{kN}$ and deflection is $10 \mathrm{~mm}$. The value of flexural strength for this specimen is $312.5 \mathrm{Mpa}$. The fractured specimen is shown in figure 10 .

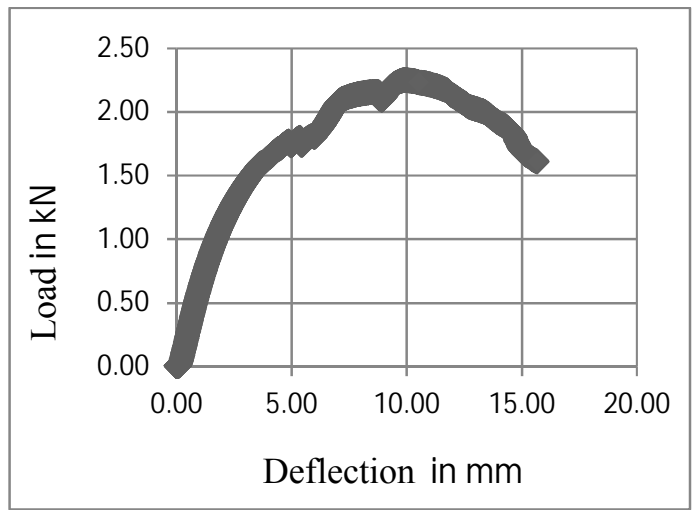

Fig. 9. Load vs deflection of $6 \mathrm{~mm}$ thick $0-90^{\circ}$ orientation glass/epoxy composite

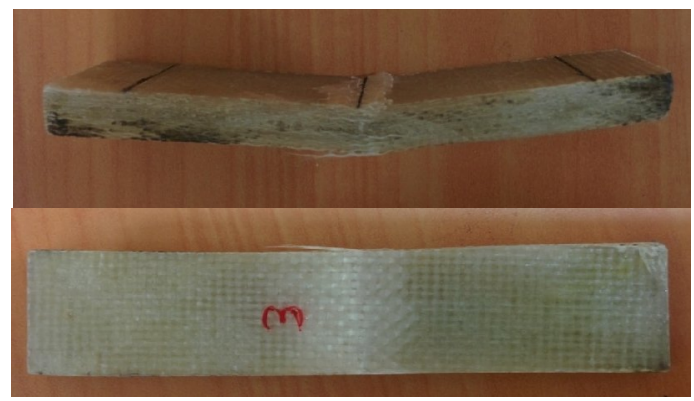

Fig 10. Fractured specimen

\subsection{Comparison of Flexural Strength}

The flexural strength of $4 \& 6 \mathrm{~mm}$ thick bidirectional glass fiber at $0-90^{0} \&-45+45^{0}$ orientation is shown in figure $11 \& 12$. The results shows that flexural strength of the glass/epoxy composite laminate at $-45+45^{0}$ fiber orientation have grater values than bidirectional glass fiber at $0-90^{\circ}$ orientation. 


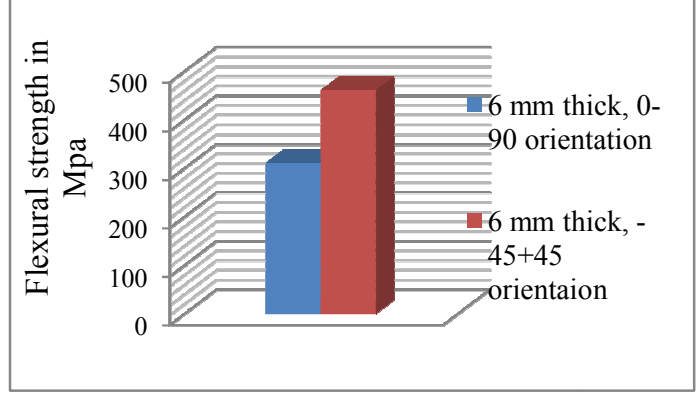

Fig 11. Flexural strengths of $6 \mathrm{~mm}$ thick specimen

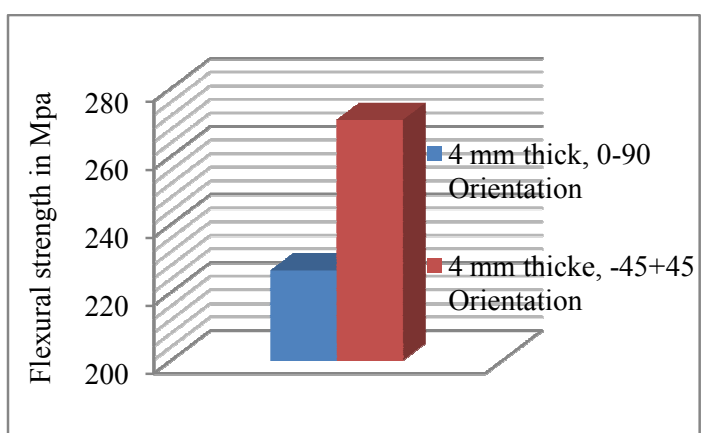

Fig 12. Flexural strengths of $4 \mathrm{~mm}$ thick specimen

\section{CONCLUSIONS}

From the experimental results the percentage difference in flexural strength for $0-90^{\circ}$ and $-45+45^{0}$ orientation fiber for 4 $\mathrm{mm}$ thick sample is 16.36 and for $6 \mathrm{~mm}$ thick sample is 32 . Hence, we can conclude that, there is an effect of fiber orientation on the flexural strength of glass/epoxy composite material.

\section{ACKNOWLEDGEMENTS}

I would like to thank my family and friends for their support and encourgment for doing this project. I would like to thank the God of my life for enlightening me.

\section{REFERENCES}

[1]. K. G. Satis, B. Siddeswarappa2, K. Mohamed Kaleemulla "Characterization of In-Plane Mechanical Properties of Laminated Hybrid Composites" Journal of Minerals \& Materials Characterization \& Engineering, Vol. 9, No.2, pp.105-114, 2010"

[2]. Keshavamurthy Y C, Dr. Nanjundaradhya N V, Dr. Ramesh S Sharma,Dr. R S Kulkarni, "Investigation of Tensile Properties of Fiber Reinforced Angle Ply laminated composites" International Journal of Emerging Technology and Advanced Engineering Website: www.ijetae.com (ISSN 2250-2459, Volume 2, Issue4, April 2012)

[3]. PAOLO FERABOLI, ELOF PEITSO, FRANCESCO D, ELEO ANDTYLER C, EVELAND "Characterization of Prepreg-Based Discontinuous Carbon Fiber/Epoxy Systems", Aeronautics and Astronautics, University of Washington Box 352400, Seattle, WA 98195-2400, USA [4]. O. Velecela, M. S. Found, C. Soutis "Crushing energy absorption of GFRP sandwich panels and corresponding monolithic laminates"Composites Part A-applied Science and Manufacturing - COMPOS PART A-APPL SCI MANUF 01/2007; 38(4):1149-1158. DOI:10.1016/j.compositesa.2006.06.002

[5]. Momchil Dimchev, Ryan Caeti, Nikhil Gupta, "Effect of carbon nanofibers on tensile and compressive characteristics of hollow particle filled composites"Composite Materials and Mechanics Laboratory, Department of Mechanical and Aerospace Engineering, Polytechnic Institute of New York University, Brooklyn, NY 11201, USA Materials \& Design - MATER DESIGN 01/2010; 31(3):1332-1337. DOI:10.1016/j.matdes.2009.09.007

[6]. R Velmurgan, V Manikandan, “ Mechanical properties of glass/palmyra fiber waste sandwich composite materials", Indian Journal of Engineering \& Material sciences, Vol. 12, December 2005, pp.563-570

[7]. S Channabasavaraju, Dr. H.K Shivanad, Santhosh Kumar S, "Evaluation of tensile and flexural properties of polymer matrix composites", International journal of Modern Engineering research(IJMER) vol. 3 Issue5, SpeOct.2013 pp-3317-3180, ISSN:2249-6645

[8]. Vonod B, Sudev L J, " Effect of fiber orientation on the flexural properties of PALF reinforced bisphenol composites", International Journal of science and engineering applications, Volume 2, Issue 8,2013 ISSN2319-7560 